\title{
Genetic Organization of the hrp Gene Cluster and dspAE/BF Operon in Erwinia herbicola pv. gypsophilae
}

\author{
Henia Mor, ${ }^{1}$ Shulamit Manulis, ${ }^{2}$ Michal Zuck, ${ }^{1}$ Roni Nizan, ${ }^{1}$ David L. Coplin, ${ }^{3}$ and Isaac Barash ${ }^{1}$ \\ ${ }^{1}$ Department of Plant Sciences, Faculty of Life Sciences, Tel-Aviv University, Tel-Aviv 69978, Israel; \\ 2Department of Plant Pathology, ARO, Volcani Center, Bet Dagan 50250, Israel; ${ }^{3}$ Department of Plant \\ Pathology, Ohio State University, Columbus 43210-1087, U.S.A. \\ Accepted 13 November 2000.
}

\begin{abstract}
Erwinia herbicola pv. gypsophilae induces gall formation in gypsophila that is dependent on the existence of a patho-

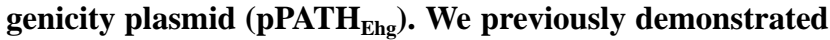
the presence of several hrp genes on this plasmid. By employing transposon mutagenesis and sequencing, a functional $h r p$ gene cluster on the pPATH $_{\text {Eng }}$ has now been characterized completely. The hrp genes of $E$. herbicola pv. gypsophilae are remarkably similar to and colinear with those of Erwinia amylovora and Pantoea stewartii and generally showed 60 to $90 \%$ nucleotide or deduced amino acid identity. E. herbicola pv. gypsophilae, however, lacks hrpW, which is present in E. amylovora. Additionally, E. herbicola pv. gypsophilae mutants deficient in harpin production retained pathogenicity and were slightly reduced in their ability to elicit a hypersensitive response (HR) in tobacco. The "disease specific" region, $d s p A / E B / F$, exhibited 60 to $74 \%$ identity with the $d s p A / E B / F$ loci of $E$. amylovora and $P$. stewartii, respectively. Mutations in $d s p A / E$ abolished pathogenicity of $E$. herbicola pv. gypsophilae but not HR elicitation on tobacco. Inactivation of HrpL reduced plant-induced transcription of $d s p A / E$ by three orders, indicating Hrp-dependent regulation.
\end{abstract}

The presence of $h r p$ genes is essential for the pathogenicity of most gram-negative phytopathogenic bacteria. Mutations in hrp genes abolish pathogenicity in susceptible host plants and the ability to elicit the hypersensitive response (HR) in resistant hosts or nonhost plants (Bonas 1994). Genetic and biochemical studies have demonstrated that hrp genes encode components of a type III secretion pathway, regulatory proteins that allow the bacteria to sense the host environment, and harpins, a class of proteinaceous elicitors of the HR in nonhost plants (Lindgren 1997). In animal and plant pathogenic bacteria, the type III secretion pathway appears to be responsible for the delivery of effector proteins into the eukaryotic host

Corresponding authors: I. Barash, E-mail: isaaci@post.tau.ac.il; and S. Manulis, E-mail: shulam@netvision.net.il

Nucleotide and/or amino acid sequence data is in the GenBank database as accession nos. AF272053, AF271716, and AF271717. cells (Galan and Collmer 1999). In gram-negative phytopathogenic bacteria, including Pseudomonas syringae, Erwinia amylovora, Erwinia carotovora, Erwinia chrysanthemi, Pantoea (Erwinia) stewartii subsp. stewartii, Xanthomonas campestris, Xanthomonas oryzae, and Ralstonia solanacearum, the $h r p$ genes are organized in clusters of 22 to $40 \mathrm{~kb}$ and contain at least six to eight complementation groups (Bonas 1994; Lindgren 1997). The nucleotide sequences of hrp gene clusters revealed high similarities between pathogens belonging to different genera, and certain genes appear to be highly conserved (Bogdanove et al. 1996a). Earlier studies have demonstrated that the hrp clusters of E. amylovora and $P$. syringae are closely related yet distinct from the hrp genes of $X$. campestris and $R$. solanacearum, which are similar and form a second lineage (Bonas 1994; Laby and Beer 1992).

A "disease-specific" ( $d s p)$ region next to the hrp gene cluster of E. amylovora is required for pathogenicity but not for HR elicitation. This region has been characterized (Bogdanove et al. 1998a; Gaudriault et al. 1997) and contains the 6.6-kb $d s p A / E B / F$ operon, which is homologous to $a v r E$ of $P$. syringae pv. tomato. The avrE locus in trans partially restored virulence to a $d s p A / E$ mutant strain of $E$. amylovora (Bogdanove et al. 1998a). The predicted DspA/E protein is large $(198 \mathrm{kDa})$ opposed to the small protein encoded by $d s p B / F(16 \mathrm{kDa})$.

In the gall-forming bacterium Erwinia herbicola (Pantoea agglomerans) pv. gypsophilae, we previously reported that hrp genes are homologous to and colinear with the hrpJ operon of E. amylovora (Nizan et al. 1997). E. herbicola generally is an epiphyte that is present on many different plants. Some strains of this bacterium such as E. herbicola pv. gypsophilae and E. herbicola pv. betae induce gall formation on gypsophila (Cooksey 1986) or on gypsophila and beet (Burr et al. 1991), respectively. The pathogenicity of both pathovars is dependent on a similar pathogenicity plasmid (designated $\mathrm{pPATH}_{\mathrm{Ehg}}$ or $\mathrm{pPATH}_{\mathrm{Ehb}}$ ), which is present exclusively in pathogenic strains (Manulis et al. 1991; I. Barash and S. Manulis, unpublished). The pPATH $\mathrm{H}_{\mathrm{Ehg}}$ contains genes involved in virulence of E. herbicola pv. gypsophilae, including genes responsible for biosynthesis of indole-3-acetic acid and cytokinins (Clark et al. 1993; Lichter et al.1995a; Lichter et al. 
1995b), genes determining host specificity of E. herbicola pv. gypsophilae on gypsophila (Ezra et al. 2000; Valinsky et al. 1998), and hrp genes (Nizan et al. 1997). The plasmid also contains several copies of an insertion element, IS1327, which may have played a role in the horizontal transfer of the hrp genes (Lichter et al. 1996). The discovery of hrp genes in $E$. herbicola pv. gypsophilae and E. herbicola pv. betae was the first report that a type III secretion system is an important determinant of pathogenicity in gall-forming bacteria. It is noteworthy that the tumorigenic bacterium Agrobacterium tumefaciens does not posses a hrp cluster (Laby and Beer 1992). The aims of this study were to demonstrate that a full and functional $h r p-d s p$ gene cluster resides on the $\mathrm{pPATH}_{\mathrm{Ehg}}$ plasmid and to determine the role of harpin and the $d s p A / E B / F$ operon in pathogenicity of E. herbicola pv. gypsophilae.

The bacterial strains, cosmids, and plasmid constructs used in this study are presented in Table 1 . Bacteria were grown in
Luria-Bertani (LB) broth or LB agar at $28^{\circ} \mathrm{C}$ for E. herbicola pv. gypsophilae and $37^{\circ} \mathrm{C}$ for Escherichia coli. Mutagenesis was carried out on two cosmid clones of pPATH Ehg $_{\text {, pLA352 }}$ and pLA244 (Fig. 1), which were obtained from a pLAFR3 library of E. herbicola pv. gypsophilae strain Ehg824-1 (Lichter et al. 1995b). Insertional mutagenesis with the transposon reporter Tn3-Spice (Lindgren et al. 1989) or mini-Tn10 (De Lorenzo et al. 1990) and construction of marker exchange mutants of the wild-type strain were performed as previously described (Lichter et al. 1995a; Nizan et al. 1997). The marker-exchange mutants were tested for pathogenicity on cuttings of Gypsophila paniculata cv. perfecta, essentially as described previously (Lichter et al. 1995a). After removal of an approximately 3-mm section from the bottom of the stem, the cutting was inoculated by dipping into a bacterial suspension of $10^{7} \mathrm{CFU} / \mathrm{ml}$ and placed in vermiculite-filled trays. The greenhouse temperature was maintained at 26 to $29^{\circ} \mathrm{C}$ and

Table 1. Bacterial strains, cosmids, and plasmids used in this study

\begin{tabular}{|c|c|c|}
\hline Strain, cosmid, plasmid & Relevant characteristics $^{\mathbf{a}}$ & Reference, source \\
\hline \multicolumn{3}{|l|}{ Escherichia coli } \\
\hline DH5 $\alpha$ & $\begin{array}{l}\mathrm{F}^{-}, \not 80 \mathrm{~d} l a c \mathrm{Z} \Delta \mathrm{M} 15, \Delta(\mathrm{lacZY} \mathrm{A}-\operatorname{argF}), \mathrm{U} 169, \text { deoR, Rec } \mathrm{A} 1, \text { end } \mathrm{A} 1, \\
\quad h s d \mathrm{R} 17\left(\mathrm{r}_{\mathrm{k}-}, \mathrm{m}_{\mathrm{k}+}\right) \sup \mathrm{E} 44, \lambda-, \text { thi-1, gyrA96, relA1 }\end{array}$ & D. Hanahan 1983 \\
\hline \multicolumn{3}{|c|}{$\begin{array}{lll} & \end{array}$} \\
\hline Ehg824-1 & Wild-type pathogenic strain Rif $^{\mathrm{T}}$ serotype 1 & Manulis et al. 1991 \\
\hline Ehg824-1Mx14, Ehg824-1Mx41 & Marker exchange mutants of $h r p N$ & This study \\
\hline Ehg824-1Мx39, Ehg824-1Mх23, Ehg824-1Мх25 & Marker exchange mutants of $d s p A / E$ & This study \\
\hline Ehg824-1Mx39(MxhrpL::aphA3) & Marker-exchange double mutant in $h r p L$ and $d s p A / E$ & This study \\
\hline \multicolumn{3}{|l|}{ Cosmids } \\
\hline pLAFR3 & $\mathrm{Tc}^{\mathrm{r}}$, broad-host-range vector IncP-1 rix RK2 ${ }^{+}$lacZa $\mathrm{Tra}^{-} \mathrm{Mob}^{+} \cos$ & Staskawicz et al. 1987 \\
\hline pLA352 & $\mathrm{Tc}^{\mathrm{r}}$, a $23.5-\mathrm{kb}$ cosmid of pPATH in pLAFR3 & Nizan et al. 1997 \\
\hline pLA244 & $\mathrm{Tc}^{\mathrm{r}} \mathrm{a} 25-\mathrm{kb}$ cosmid of pPATH in pLAFR3 & This study \\
\hline pMBN-H6.4 & $\mathrm{Tc}^{\mathrm{r}}$, a 6.4-kb HindIII fragment from pLA352 in pLAFR3 & This study \\
\hline pMBN-H4.2 & $\mathrm{Tc}^{\mathrm{r}}$, a 4.2-kb HindIII fragment from pLA352 in pLAFR3 & This study \\
\hline pMBZ-H6 & $\mathrm{Tc}^{\mathrm{r}}$, a 6-kb HindIII fragment from pLA244 in pLAFR3 & This study \\
\hline \multicolumn{3}{|c|}{ 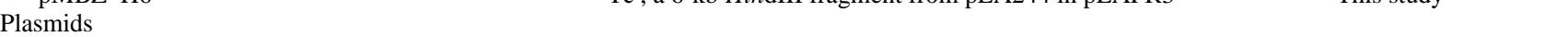 } \\
\hline pTn3-Spice & $\mathrm{Amp}^{\mathrm{r}}, \mathrm{Sp}^{\mathrm{r}}$, and clone containing the inaZ reporter gene in $\mathrm{Tn} 3$ & Ditta et al. 1980 \\
\hline pMBZ-H-R1.3 & $\begin{array}{l}\text { Amp }{ }^{\mathrm{r}} \text {, a 1.3-kb HindIII-EcoRI fragment from pLA352 in } \\
\text { pBluescript containing } h r c N\end{array}$ & This study \\
\hline PMBZ-R-H2.9 & $\begin{array}{l}\text { Ampr, a 2.9-kb EcoRI-HindIII fragment from pLA352 in } \\
\text { pBluescript containing } h r c V, h r p Q \text {, and } h r c N\end{array}$ & This study \\
\hline pMBN-H-R2.5 & $\begin{array}{l}\text { Ampr, a 2.5-kb HindIII-EcoRI fragment from pLA352 in } \\
\text { pBluescript containing } h r p J \text { and } h r p L\end{array}$ & This study \\
\hline pMBN-R2.1 & $\begin{array}{l}\text { Ampr, a } 2.1-\mathrm{kb} E c o \text { RI fragment from pLA352 in pBluescript con- } \\
\text { taining } h r p X \text { and } h r p Y\end{array}$ & This study \\
\hline pMBN-R-H1.8 & $\begin{array}{l}\text { Amp }{ }^{\mathrm{r}} \text {, a 1.8-kb EcoRI-HindIII fragment from pLA352 in } \\
\text { pBluescript containing hrpS }\end{array}$ & This study \\
\hline pMBZ-H-R2.3 & $\begin{array}{l}\text { Amp }{ }^{\mathrm{r}} \text {, a } 2.3-\mathrm{kb} \text { HindIII-EcoRI fragment from pLA244 in } \\
\text { pBluescript containing } h r p B, h r p D \text {, and } h r p E\end{array}$ & This study \\
\hline pMBH-P1.5 & $\begin{array}{l}\text { Amp } \mathrm{r} \text {, a } 1.5-\mathrm{kb} P s t \mathrm{I} \text { fragment from pLA244 in pBluescript con- } \\
\text { taining } h r p F, h r p G \text {, and } h r c C\end{array}$ & This study \\
\hline pMBH-P3 & $\begin{array}{l}\mathrm{Amp}^{\mathrm{r}} \text {, a } 3-\mathrm{kb} P s t \mathrm{I} \text { fragment from pLA244 in pBluescript containing } \\
h r c C, h r p T, h r p V \text {, and } h r p N\end{array}$ & This study \\
\hline pMBH-P1.3 & $\begin{array}{l}\text { Amp }{ }^{\mathrm{r}} \text {, a } 1.3-\mathrm{kb} P s t \mathrm{I} \text { fragment from pLA244 in pBluescript con- } \\
\text { taining } h r p N \text { and } d s p E / A\end{array}$ & This study \\
\hline pMBH-H-P0.7 & $\begin{array}{l}\mathrm{Amp}^{\mathrm{r}} \text {, a 0.7-kb HindIII-PstI fragment from pLA244 in pBluescript } \\
\quad \text { containing } d s p A / E\end{array}$ & This study \\
\hline pMBH-H2.5 & $\begin{array}{l}\text { Ampr, a } 2.5-\mathrm{kb} H i n d I I I \text { fragment from pLA244 in pBluescript } \\
\text { containing } d s p A / E\end{array}$ & This study \\
\hline pMBH-H0.5 & $\begin{array}{l}\mathrm{Amp}^{\mathrm{r}} \text {, a } 0.5-\mathrm{kb} H \text { HindIII fragment from pLA244 in pBluescript } \\
\text { containing } d s p A / E\end{array}$ & This study \\
\hline pMBH-H-P1.3 & $\begin{array}{l}\text { Amp }^{\mathrm{r}} \text {, a } 1.3-\mathrm{kb} \text { HindIIII-PstI fragment from pLA244 in pBluescript } \\
\text { containing } d s p A / E\end{array}$ & This study \\
\hline pMBH-P-H2.3 & $\begin{array}{l}\mathrm{Amp}^{\mathrm{r}} \text {, a } 2.3-\mathrm{kb} P \text { Pst }- \text { HindIII fragment from pLA244 in pBluescript } \\
\text { containing } d s p A / E\end{array}$ & This study \\
\hline pMBH-K1.5 & $\begin{array}{l}\text { Amp } p^{\mathrm{r}} \text {, a 2.3-kb KpnI fragment from pLA244 in pBluescript con- } \\
\quad \text { taining } d s p A / E\end{array}$ & This study \\
\hline
\end{tabular}

a Antibiotics used per ml: $100 \mu \mathrm{g}$ of ampicillin, $50 \mu \mathrm{g}$ of kanamycin, $50 \mu \mathrm{g}$ of spectinomycin, and $100 \mu \mathrm{g}$ of rifampicin. 
high humidity was generated by computer-controlled mist sprinklers. Gall formation was scored 14 days after inoculation, as described elsewhere (Lichter et al. 1995a). Hypersensitivity tests were carried out in tobacco leaves (Nicotiana tabacum L. "Hicks"), according to Nizan et al. (1997). Isolation of plasmid DNA from E. coli, restriction enzyme digestions, subcloning, transformations, Southern analysis, Western blots, and polymerase chain reaction were carried out by standard procedures (Ausubel et al. 1995) or as recommended by the suppliers. Primers were synthesized by GIBCO-BRL (Glasgow, Scotland).

The hrp gene cluster initially was mapped on the overlapping cosmids pLA352 and pLA244 (Fig. 1) by saturation mutagenesis with Tn3-Spice and mini-Tn10 (results not shown). The location of the insertions in mutants that were not pathogenic in gypsophila and failed to elicit HR in tobacco (i.e., with a $\mathrm{Hrp}^{-}$phenotype) was determined, as previously described (Nizan et al. 1997). DNA fragments from the region containing the $\mathrm{Hrp}^{-}$mutations were subcloned into pBluescript $\left(\mathrm{KS}^{+}\right)$for sequencing, and the resulting series of plasmids were designated $\mathrm{pMBH}, \mathrm{pMBN}$, and $\mathrm{pMBZ}$, with a plasmid number designating the size of the insert (Table 1). Unidirectional deletions of the cloned fragment were generated with the Erase-a-Base kit (Promega, Madison, WI, U.S.A.). Automated sequencing with Taq DNA polymerase was carried out at the Laboratories for Biological Services, Tel-Aviv University. When necessary, the sequence was completed by walking with custom primers. Analysis of sequence data for DNA and deduced protein sequences was performed with the Wisconsin Package, version 9 (Genetic Computer Group, Madison, WI, U.S.A.).

We previously reported that the sequence of a $3.8-\mathrm{kb}$ HindIII DNA fragment from pLA352 (GenBank accession no. X99768) contained six complete and two partial open reading frames (ORFs) with high homology and colinearity to the following genes in the HrpJ operon of E. amylovora: HrpO, HrpP, HrcQ, HrcR, HrcS, HrcT, and HrcU (Table 2) (Nizan et al. 1997). These proteins appeared to be components of a type
III secretion system on the basis of their homology to $E$. amylovora Hrp proteins (Bogdanove et al. 1996a; Bogdanove et al. 1996b). To delineate the complete hrp gene cluster of $E$. herbicola pv. gypsophilae, the region containing the Hrpmutants was sequenced. The pLA352 and pLA244 subclones used for sequencing are described in Table 1. The sequences of the regulatory genes ( $h r p L, h r p X Y$, and $h r p S$ ), $h r p N$ and $d s p A / E B / F$ operon were submitted to GenBank as accession nos. AF272053, AF271716, and AF271717 respectively.

The results shown in Table 2 indicate that the E. herbicola pv. gypsophilae hrp gene cluster and $d s p A / E B / F$ operon are remarkably similar in their organization and sequence to that of the E. amylovora hrp cluster. With few exceptions, the percent identities of E. herbicola pv. gypsophilae nucleotides and deduced proteins with those of E. amylovora ranged from 60 to $96 \%$. Similar high identities also were observed with available $h r p$ gene sequences of P. stewartii DC283 (Table 2). The hrp gene cluster of E. herbicola pv. gypsophilae appeared to contain genes for all required Hrp functions, namely protein secretion via the type III system (i.e., $h r p J, h r p A$, and $h r p C$ operons), regulation (i.e., $h r p X Y, h r p S$, and $h r p L$ operons) and HR elicitation on nonhost plants (i.e., $h r p N$ ) (Kim et al. 1997). The nine broadly conserved genes designated $h r c$ (Bogdanove et al. 1996a) also were present (Table 2). Comparison of the hrp genes of E. herbicola pv. gypsophilae with other plant and animal pathogenic bacteria showed that the highest homologies were obtained with E. amylovora or P. stewartii subsp. stewartii.

The only major difference between the hrp cluster of $E$. herbicola pv. gypsophilae and E. amylovora is located in the space between the $h r p N$ and $d s p A / E B / F$ (Fig. 1). In E. herbicola pv. gypsophilae, this region was $1 \mathrm{~kb}$ compared with $4 \mathrm{~kb}$ in E. amylovora, where four ORFs are arranged in two operons (Kim and Beer 1998). One of the ORFs in E. amylovora is $h r p W$. The HrpW protein resembles harpin in its high glycine content, but it also has homology to pectate lyase. The Nterminal domain of HrpW in E. amylovora was sufficient to elicit HR, but the C-terminal pectate lyase domain did not
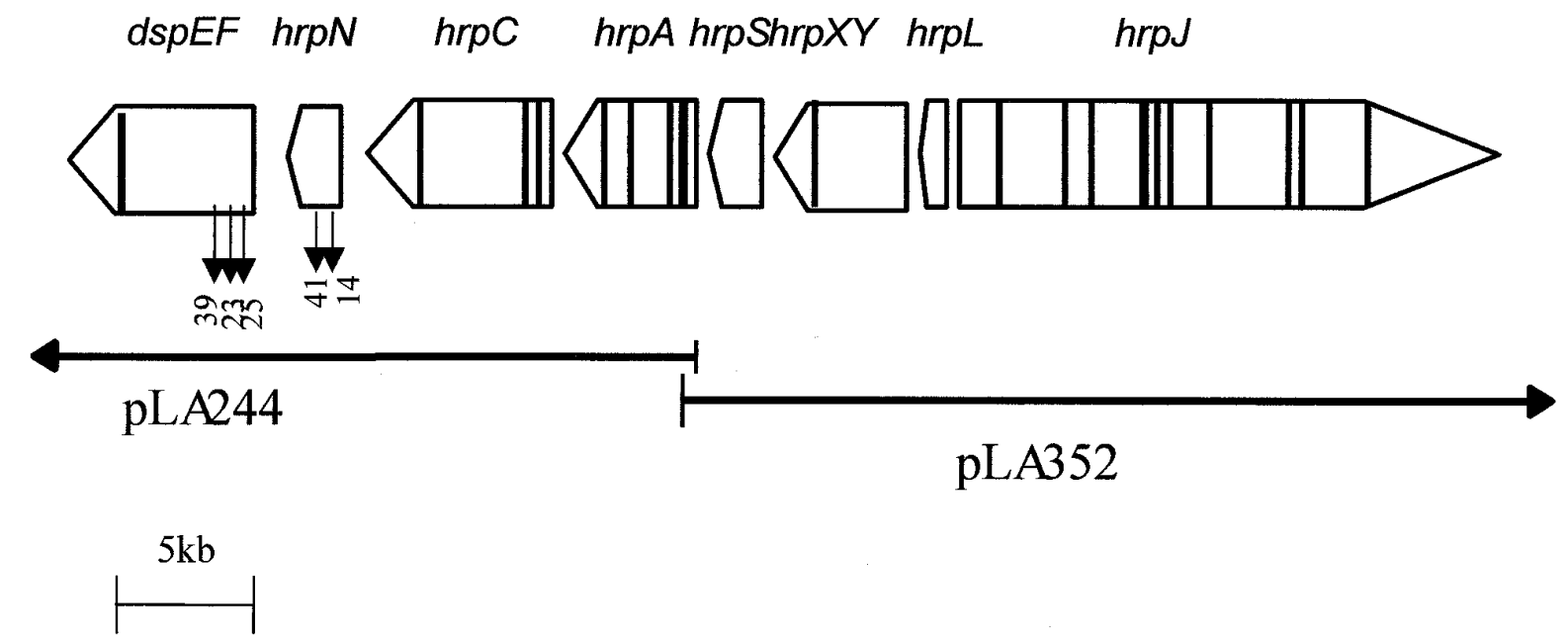

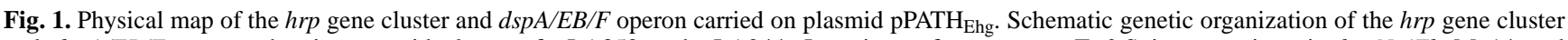
and $d s p A / E B / F$ operon showing cosmid clones of pLA352 and pLA244. Locations of transposon Tn3-Spice mutations in hrpN (EhgMx14 and $E h g \mathrm{Mx} 41)$ and $d s p A / E B / F(E h g \mathrm{Mx} 39, E h g \mathrm{Mx} 23$, and $E h g \mathrm{Mx} 25)$ are indicated by numbers. Borders between $h r p$ genes within the operons are indicated by vertical lines. 
exhibit any enzymatic activity (Kim and Beer 1998). Although HrpW appears to be distributed widely among several Erwinia species (Kim and Beer 1998), only a remnant of this gene $(50 \mathrm{bp})$ was detected in E. herbicola pv. gypsophilae. Although HrpW may contribute to HR elicitation in nonhosts, its function is not entirely clear because $h r p W$ mutants in either E. amylovora or $P$. syringae pv. tomato retained wild-type ability to elicit the HR in nonhosts and to cause disease (Charkowski et al. 1998; Kim and Beer 1998).

In order to assess the role of harpin in pathogenicity of $E$. herbicola pv. gypsophilae, pLA244 was digested with HindIII and a 6-kb fragment was cloned into pLAFR3 to yield pMBZH6. Sequence analysis confirmed the presence of $h r p N$ in the cloned fragment. PMBZ-H6 was subjected to mutagenesis with Tn3-Spice (Lindgren et al. 1989). Two mutations in $h r p N$ were marker exchanged into Ehg824-1 to obtain EhgMx14 and EhgMx41 (Fig. 1). To confirm that the resulting mutants could not produce harpin, protein extracts from cells of Ehg824-1, PnssDC283, and the two marker-exchanged mutants were subjected to Western blotting (Fig. 2), with $P$. stewartii subsp. stewartii antiharpin polyclonal antibodies (M. Ahmad and D. Coplin, unpublished). The results clearly indi-

Table 2. Comparison of hrp gene sequences from Erwinia herbicola pv. gypsophilae with corresponding genes of Erwinia amylovora and Pantoea stewartii subsp. stewartii

\begin{tabular}{|c|c|c|c|c|}
\hline \multirow[b]{3}{*}{ Gene $^{\mathbf{a}}$} & \multicolumn{4}{|c|}{ Percentage of identity } \\
\hline & \multicolumn{2}{|c|}{ E. amylovora } & \multicolumn{2}{|c|}{ P. stewartii } \\
\hline & Nucleotides & Amino acids & Nucleotides & Amino acids \\
\hline hrpJ & 70 & 66.9 & & \\
\hline$h r c V$ & 78 & 84 & & \\
\hline$h \mathrm{r} p \mathrm{Q}$ & 69 & 65 & & \\
\hline$h r c N$ & 79 & 80 & & \\
\hline hrpO & 69.3 & 60.8 & & \\
\hline hrpP & 65.1 & 64.3 & & \\
\hline $\operatorname{hrc} Q$ & 66.7 & 73.4 & & \\
\hline$h r c R$ & 80.1 & 90.4 & & \\
\hline $\mathrm{HrcS}$ & 80.3 & 96 & & \\
\hline$H r c T$ & 76.3 & 81.5 & & \\
\hline$H r c U$ & $89(150 \mathrm{bp})^{\mathrm{b}}$ & $94.4(50 \mathrm{aa})$ & & \\
\hline$H r p L$ & 70.2 & 77.4 & 77.8 & 80.8 \\
\hline$h r p X$ & 71.7 & 71.7 & 78 & 79.6 \\
\hline$h r p Y$ & 78.2 & 75.3 & 82.2 & 88.7 \\
\hline hrpS & 75.3 & 83.6 & 77 & 79.5 \\
\hline hrpA & 73 & 66.7 & 78 & 73 \\
\hline hrpB & $\begin{array}{l}81.5 \\
\quad(136 \mathrm{bp})\end{array}$ & $100(24 \mathrm{aa})$ & $86(130 \mathrm{bp})$ & 95 (22 aa) \\
\hline hrcJ & $83(263 \mathrm{bp})$ & 85 ( 87 aa) & $\begin{array}{l}81.2 \\
\quad(263 \mathrm{bp})\end{array}$ & $80(87$ aa $)$ \\
\hline$h r p D$ & 66.6 & 63.2 & 72.2 & 65 \\
\hline hrpE & 64 & 62.6 & 70 & 62.2 \\
\hline$h r p F$ & 75 & 75 & 80 & 82 \\
\hline$h r p G$ & 64 & 47 & 67.4 & 56 \\
\hline $\operatorname{hrcC}$ & 73 (1,529 bp) & $85(200 \mathrm{aa})$ & $\begin{array}{l}74.4 \\
\quad(1,550 \mathrm{bp})\end{array}$ & $86(207 a a)$ \\
\hline$h r p T$ & 67 & 62.5 & 75 & 72.3 \\
\hline$h r p V$ & 68 & 68 & 70 & 65 \\
\hline$h r p N$ & 64 & 60 & 73.8 & 69.7 \\
\hline$D s p A / E$ & 65 & 61 & 73.5 & 75 \\
\hline$D s p B / F$ & 72 & 65.3 & 73.8 & 65.3 \\
\hline
\end{tabular}

a Open reading frame (ORF) sequences of E. herbicola pv. gypsophilae were named according to their homology with E. amylovora hrp genes. Sequences of hrp genes from P. stewartii subsp. stewartii were obtained from GenBank, accession no. AF282857.

${ }^{\mathrm{b}}$ Number of base pairs or deduced amino acids of partially sequenced ORFs is indicated by parentheses. cated that EhgMx41 and EhgMx14 were deficient in harpin production (Fig. 2). The two mutants were then tested for pathogenicity on gypsophila cuttings and for HR elicitation in tobacco leaves. Both mutants retained full pathogenicity, and a slight reduction in the necrotic area caused by the HR response was observed compared with the wild type. These results are similar to the phenotypes exhibited by harpin mutants of other bacterial plant pathogens. For example, $h r p \mathrm{~N}$ or hrpZ mutations abolish HR elicitation in E. amylovora Ea321 (Wei et al. 1992) greatly reduce the HR produced by E. amylovora CFBP1430 (Barny 1995) or E. chrysanthemi (Bauer et al. 1995) but have little or no effect on HR elicitation by $P$. syringae (Alfano et al. 1996). Similarly, mutations in $\mathrm{HrpN}_{\mathrm{Ehg}}$ and $\mathrm{HrpN}_{\text {Pnss }}$ did not exhibit any effect on pathogenicity of $E$. herbicola pv. gypsophilae or P. stewartii subsp. stewartii (D. Coplin, unpublished), respectively. Unlike E. herbicola pv. gypsophilae, however, loss of hrpN of P. stewartii subsp. stewartii greatly reduced HR elicitation.

It is noteworthy that the apparent molecular mass of $\mathrm{HrpN}_{\text {Ehg }}$ was slightly lower than that of $\mathrm{HrpN}_{\text {Pnss }}$, but both were 41 to $44 \mathrm{kDa}$ (Fig. 2). Despite common physical and chemical properties, e.g., heat stable, glycine rich, and acidic, the harpins from different genera seem to be quite distinct from each other in regard to their amino acid composition (Lindgren 1997). The percent identities of $\mathrm{HrpN}_{\text {Ehg }}$ with harpins of $P$. stewartii subsp. stewartii, E. amylovora, E. chry-

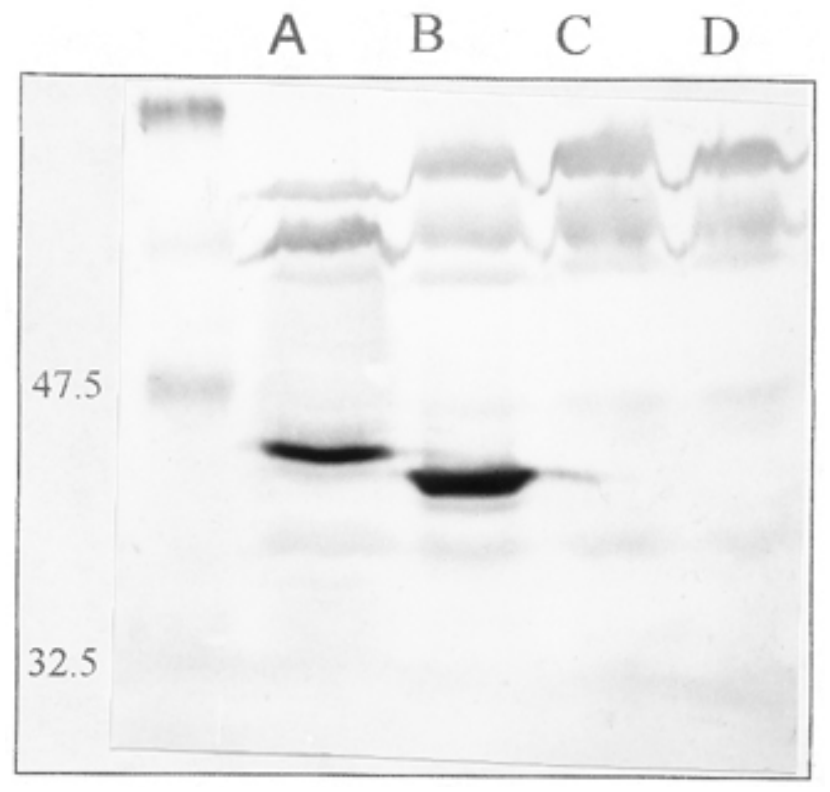

Fig. 2. Immunoblot analysis of harpin ${ }_{\text {Ehg }}$ production in Ehg824-1 and its $h r p N$ mutants. To induce harpin production, plasmid pVSP61 containing the regulatory gene $h r p S$ under a lac promoter $\left(\mathrm{P}_{\text {lac }}: h r p S\right)(\mathrm{R}$. Nizan, unpublished) was mobilized into Ehg824-1, EhgMx14, and EhgMx41 by triparental mating. The transconjugants were then grown in $3 \mathrm{ml}$ of LuriaBertani medium for $10 \mathrm{~h}$ at $28^{\circ} \mathrm{C}$ in the presence of $1.5 \mathrm{mM}$ isopropyl- $\beta$-Dthiogalactoside. Pantoea stewartii DC283 was similarly grown in inducing medium (Nizan et al. 1997). Bacterial cells were centrifuged, resuspended in loading buffer, and heated at $100^{\circ} \mathrm{C}$ for $3 \mathrm{~min}$ and then loaded onto a sodium dodecyl sulfate-10\% polyacrylamide gel. Western blotting was carried out with antiharpin antibodies prepared against $\mathrm{HrpN}_{\text {Pnss }}$ from DC283 (D. L. Coplin, unpublished). Lane A: PnssDC283; B: Ehg824-

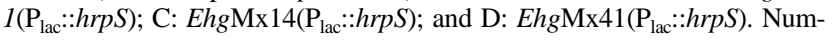
bers indicate protein mass in kilodaltons. 
santhemi, and E. carotovora were $69,60,52$, and $48 \%$ respectively.

In order to test the functionality of the type III protein secretion system in E. herbicola pv. gypsophilae, the secretion of harpin into the medium was compared between Ehg824-1 and its marker-exchanged mutant no. 19 (Nizan et al. 1997). In the latter strain, the mutation resides in $h r p Q$ of the $h r p J$ operon encoding for proteins of the type III system (Table 2). Following introduction of $\mathrm{P}_{\text {lac }}: h r p \mathrm{~S}$, the wild type and the mutant were grown in LB. Harpin could be detected by immunoblotting in concentrated medium of the wild-type transconjugant but not of the mutant, suggesting a type IIIdependent secretion.

As described above, the $d s p A / E B / F$ operon of $E$. herbicola pv. gypsophilae was completely sequenced. The $d s p A / E$ and $d s p B / F$ ORFs were 5.5 and $0.38 \mathrm{~kb}$, respectively, encoding predicted proteins of 201.2 and $13.7 \mathrm{kDa}$. A potential " $h r p$ box" promoter was identified 109 bp upstream of the operon (GGAACC-N ${ }_{15}$-CCCAC). The percentage of amino acid identities of DspA/E with that of E. amylovora and of $P$. stewartii subsp. stewartii were 61 and $75 \%$, respectively, whereas $\mathrm{DspB} / \mathrm{F}$ exhibited $65.3 \%$ identity with both bacteria (Table 2). Three marker-exchanged mutants, EhgMx23, EhgMx25, and EhgMx39 (Fig. 1), were generated by mutagenesis of pMBZ-H6 with the inaZ reporter transposon Tn3-Spice. Mutations in $d s p A / E$ completely abolished pathogenicity but did not affect HR elicitation on tobacco. Transcription of $d s p A / E$ was determined by Tn3-Spice inaZ gene fusions (Lindgren et al. 1989). To demonstrate whether $d s p A / E$ is Hrp-regulated, a kanamycin cassette was inserted into hrpL of EhgMx39 (Table 1) to yield the double mutant EhgMx39(MxhrpL::aphA3). For hrp-induction in planta, three gypsophila cuttings were inoculated by dipping them into cell suspensions (approximately $10^{9} \mathrm{CFU} / \mathrm{ml}$ ) of EhgMx39(MxhrpL::aphA3) and EhgMx39. Following incubation overnight under humid conditions at $25^{\circ} \mathrm{C}$, the cuttings were washed with water and $1 \mathrm{~cm}$ of the lower part of the stem was removed and ground in water for determination of ice nucleation activity. The log of ice nuclei per cell for the $\mathrm{HrpL}^{-} \mathrm{mu}-$ tant EhgMx39(MxhrpL::aphA3) was -5.55 compared with -2.86 for EhgMx39). These results indicate that inactivation of $h r p L$ reduced the transcriptional activity of $d s p A / E$ by almost three orders. Thus, the transcription of $d s p A / E$ in Ehg824-1 is under Hrp regulation, as reported for E. amylovora (Bogdanove et al. 1998b; Gaudriault et al. 1997).

The results of this study clearly demonstrate that the pPATH plasmid of E. herbicola pv. gypsophilae carries a fully functional $h r p$ gene cluster and $d s p A / E B / F$ operon, very similar to $E$. amylovora and $P$. stewartii. Because the hrp gene cluster of E. herbicola pv. gypsophilae resides on a plasmid instead of the chromosome, as it does in other erwinias, we speculate it was mobilized by horizontal transfer from other bacteria, presumably Erwinia spp. into E. herbicola pv. gypsophilae.

\section{ACKNOWLEDGMENTS}

This study was supported by research grant 45-2816-96 from BARD, the U.S.-Israel Binational Agricultural Research and Development Fund, and by the DFG program for Trilateral Cooperation among Israel, Palestine, and Germany (grant EI 1440/11-1).

\section{LITERATURE CITED}

Alfano, J. R., Bauer, D. W., Milos, T. M., and Collmer, A. 1996. Analysis of the role of the Pseudomonas syringae pv. syringae HrpZ harpin in elicitation of the hypersensitivity response in tobacco using functionally nonpolar deletion mutation, truncated HrpZ fragments, and hrmA mutations. Mol. Microbiol. 19:715-728.

Ausubel, F. M., Brent, R., Kingston, R. E., Moore, D. D., Seidman, J. G., Smith, J. A., and Struhl, K. 1995. Current Protocols in Molecular Biology. John Wiley \& Sons, New York.

Barny, M. A. 1995. Erwinia amylovora hrpN mutants, blocked in harpin synthesis, expressed a reduced virulence on host plants and elicit variable hypersensitive reactions on tobacco. Eur. J. Plant Pathol. 101:333-340.

Bauer, D. W., Wei, Z.-M., Beer, S. V., and Collmer, A. 1995. Erwinia

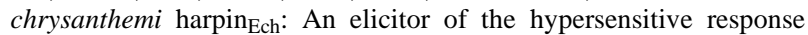
that contributes to soft-rot pathogenesis. Mol. Plant-Microbe Interact. 8:484-491.

Bogdanove, A. J., Beer, S. V., Bonas, U., Boucher, C. A., Collmer, A., Coplin, D. L., Cornelius, G. R., Huang, H. C., Hutcheson, S. W., Panopoulus, N. J., and Van Gijsegem, F., 1996a. Unified nomenclature for broadly conserved hrp genes of phytopathogenic bacteria. Mol. Microbiol. 20:681-683.

Bogdanove, A. J., Wei, Z. M., Zhao, L., and Beer, S. V. 1996b. Erwinia amylovora secretes harpin via a type III pathway and contains a homolog of yopN of Yersinia. J. Bacteriol. 178:1720-1730.

Bogdanove, A. J., Kim, J. F., Wei, Z.-M., Kolchinsky, P., Charkowski, A. O., Conlin A. K., Collmer, A., and Beer, S.V. 1998a. Homology and functional similarity of an hrp-linked pathogenicity locus, dspEF, of Erwinia amylovora and the avirulence locus avrE of Pseudomonas syringae pathovar tomato. Proc. Natl. Acad. Sci. USA 95:1325-1330.

Bogdanove, A., Bauer, W. B., and Beer, S. V. 1998b. Erwinia amylovora secretes DspE, a pathogenicity factor and functional AvrE homolog through the Hrp (type III secretion) pathway. J. Bacteriol. 180:22442247.

Bonas, U. 1994. hrp genes of phytopathogenic bacteria. Curr. Top. Microbiol. Immunol. 192:79-98.

Burr, T. J., Katz, B. H., Abawi, G. S., and Crosier, D. C. 1991. Comparison of tumorigenic strains of Erwinia herbicola isolated from table beet with E. h. gypsophilae. Plant Dis. 75:855-858.

Charkowski, A. O., Alfano, J. R., Preston, G., Yuan, J., He, S. Y., and Collmer, A. 1998. The Pseudomonas syringae pv. tomato $\mathrm{HrpW}$ has domains similar to harpins and pectate lyases and can elicit the plant hypersensitive response and bind pectate. J. Bacteriol. 180:52115217.

Clark, E., Manulis, S., Ophir, Y., Barash, I., and Gafni, Y. 1993. Cloning and characterization of iaaM and iaaH from Erwinia herbicola pathovar. gypsophilae. Phytopathology 83:234-240.

Cooksey, D. A. 1986. Galls of Gypsophila paniculata caused by Erwinia herbicola. Plant Dis. 70:464-468.

De Lorenzo, V., Herrero, M., Jakubzik, U., and Timmis, K. N. 1990. Mini-Tn 5 transposon derivatives for insertion mutagenesis, promoter probing, and chromosomal insertion of cloned DNA in gram negative eubacteria. J. Bacteriol. 172:6568-6572.

Ditta, G., Stanfield, S., Corbin, D., and Helinsky, D. R. 1980. Broad host range DNA cloning system for gram-negative bacteria: Construction of a gene bank of Rhizobium meliloti. Proc. Natl. Acad. Sci. USA 77:7343-7351.

Ezra, D., Barash, I., Valinsky, L., and Manulis, S. 2000. The dual function in virulence and host range restriction of a gene isolated from

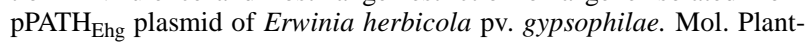
Microbe Interact. 13:683-692.

Galan, J. E., and Collmer, A. 1999. Type III secretion machines: Bacterial devices for protein delivery into host cells. Science 284:13221328.

Gaudriault, S., Malandrin, L., Paulin, J.-P., and Barny, M.-A. 1997. DspA, an essential pathogenicity factor of Erwinia amylovora showing homology with AvrE of Pseudomonas syringae, is secreted via the Hrp secretion pathway in a DspB dependent way. Mol. Microbiol. 26:1057-1069.

Hanahan, D. 1983. Studies on transformation of Escherichia coli with plasmids. J. Mol. Biol. 166:557-580.

Kim, J., Wei, Z., and Beer, S. 1997. hrpA and hrpC operons of Erwinia amylovora encode components of a type III pathway that secretes 
harpin. J. Bacteriol. 179:1690-1697.

Kim, J. F., and Beer, S. V. 1998. HrpW of Erwinia amylovora, a new harpin that contains a domain homologous to pectate lyases of a distinct class. J. Bacteriol. 180:5203-5210.

Laby, R. J., and Beer, S. V. 1992. Hybridization and functional complementation of the hrp gene cluster from Erwinia amylovora strain Ea321 with DNA of other bacteria. Mol. Plant-Microbe Interact. 5:412-419.

Lichter, A., Barash, I., Valinsky, L., and Manulis, S. 1995a. The genes involved in cytokinin biosynthesis in Erwinia herbicola pv. gypsophilae: Characterization and role in gall formation. J. Bacteriol. 177:4457-4465.

Lichter, A., Manulis, S., Sagee, O., Gafni, Y., Gray, J., Meilan, R., Morris, R. O., and Barash, I. 1995b. Production of cytokinins by Erwinia herbicola pv. gypsophilae and isolation of a locus conferring cytokinin biosynthesis. Mol. Plant-Microbe Interact. 8:114-121.

Lichter, A., Manulis, S., Valinsky, L., Karniol, B., and Barash, I. 1996. IS1327, a new insertion-like element in the pathogenicity-associated plasmid of Erwinia herbicola pv. gypsophilae. Mol. Plant-Microbe Interact. 9:98-104.

Lindgren, P. B. 1997. The role of $h r p$ genes during plant-bacterial interactions. Annu. Rev. Phytopathol. 35:129-152.

Lindgren, P. B., Frederick, R., Govindarajan, A. G., Panopoulos, N. J.,
Staskawicz, B. J., and Lindow, S. E. 1989. An ice nucleation reporter gene system: Identification of inducible pathogenicity genes in Pseudomonas syringae pv. phaseolicola. EMBO J. 8:1291-1301.

Manulis, S., Gafni, Y., Clark, E., Zutra, D., Ophir, Y., and Barash, I. 1991. Identification of a plasmid DNA probe for detection of Erwinia herbicola pathogenic on Gypsophila paniculata. Phytopathology 81:54-57.

Nizan, R., Barash, I., Valinsky, L., Lichter, A., and Manulis, S. 1997. The presence of $h r p$ genes on the pathogenicity-associated plasmid of the tumorigenic bacterium Erwinia herbicola pv. gypsophilae. Mol. Plant-Microbe Interact. 10:677-682.

Staskawicz, B., Dhalbeck, D., Keen, N. T., and Napoli C. 1987. Molecular characterization of cloned avirulence genes from race 0 and race 1 of Pseudomonas syringae pv. glycinea. J. Bacteriol. 169:57895794.

Valinsky, L., Manulis, S., Nizan, R., Ezra, D., and Barash, I. 1998. A pathogenicity gene isolated from the pPATH of Erwinia herbicola pv. gypsophila determines host specificity. Mol. Plant-Microbe Interact. 11:753-762.

Wei, Z.-M., Laby, R. J., Zumoff, C. H., Bauer, D. W., He, S. Y., Collmer, A., and Beer, S.V. 1992. Harpin, elicitor of the hypersensitive response produced by the plant pathogen Erwinia amylovora. Science 257:85-88. 